\title{
The word on popular science
}

\section{To mark UNESCO's World Book and Copyright Day on 23 April, Josie Glausiusz asks science editors at leading book publishers about trends and technology.}

A nimated, interactive, and evolving at the reader's command: this is the popular science book of the near future, according to T. J. Kelleher, the science commissioning editor at Basic Books in New York.

"We can expect to see new kinds of books that would have been impossible on paper," Kelleher says. "The straightforward book that is nothing but words is not going any place; people obviously like to read, but there are other ways they can experience information." So a mathematics e-book might incorporate a user interface that lets readers change variables: for example, the density, volume and speed of an asteroid hurtling towards Earth.

Basic Books has already taken the plunge. In October 2012, the company published a version of Richard Feynman's Six Easy Pieces for the iPad that incorporates audio recordings of Feynman's physics lectures at the California Institute of Technology in Pasadena - and 5,000 photographs of the revered Nobel laureate delivering them.

My poll of science editors at major publishers revealed enthusiasm for apps and e-books. In September 2011, Farrar, Straus and Giroux (FSG), in a joint imprint with Scientific American, launched its first app. Journey to the Exoplanets has more than
100 illustrations, as well as essays and audio clips from planetary scientists, including Caleb Scharf and Lawrence Krauss.

The electronic format, says Latha Menon, a senior commissioning editor at Oxford University Press in Oxford, UK, is "ideal for transmitting science ideas", because animations can be used to illustrate processes such as natural selection. In one example, she says, "you can actually see how the lightgrey moths are picked off" in preference to dark moths camouflaged by soot-grimed tree trunks, an adaptation seen during the industrial revolution.

And, notes FSG senior editor Amanda Moon, "the thirst for knowledge about topics that fall under the broad umbrella of 'science' is intensifying. We all have questions about evolution, technology, psychology, animal behaviour." Others echo her, although with none prepared to divulge exact sales figures, it is hard to know whether their enthusiasm reflects profits.

The science books that find a devoted readership these days, says Moon, "boast provocative arguments grounded in original research, are character-driven narratives and, in many cases, offer counterintuitive angles on seemingly familiar topics". She

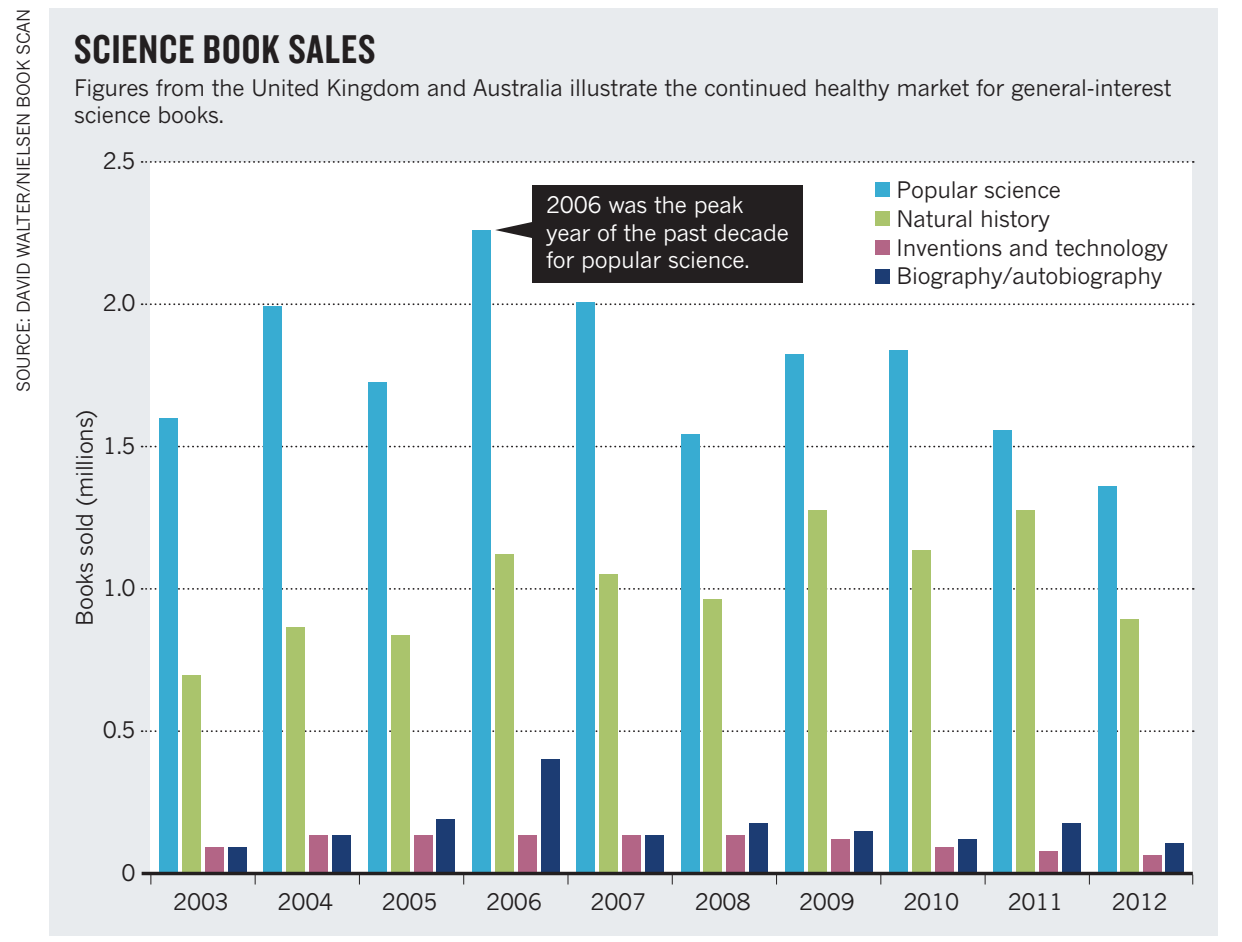

cites Kevin Dutton's The Wisdom of Psychopaths (Scientific American, 2012), which suggests how we can learn from "functional psychopaths" such as some neurosurgeons and lawyers. Authors, she adds, now have many more opportunities to get the word out about groundbreaking ideas and research through platforms such as Facebook, Twitter and Goodreads.

Many of today's readers are prepared for a challenge. "What's interesting," says Menon, "is that there seems to be a significant market of people out there who perhaps studied some science or even did a science degree", and then went off to do something else. That readership, Menon adds, is sophisticated, demanding books that are "conceptually, a little stretching": for example, Jim Baggott's The Quantum Story (Oxford Univ. Press, 2011), a history of quantum theory from 1900 to the present in 40 key moments. Epigenetics, neuroscience and particle physics - the last prompted by the discovery last year of a Higgs boson - are currently big, she says. Although, as in every other field, science book publishing is dominated by television tie-ins and celebrity authors such as Brian Cox and Stephen Hawking.

Christie Henry, editorial director of sciences and social sciences at the University of Chicago Press in Illinois, concurs that, at present, the public appetite for science seems voracious (see 'Science book sales'). "The most pressing issues we face as a global society rely on science to some extent," she says. Books on water rights, infectious diseases, conservation and marine science are all proving popular, she explains.

All agree that well-written science books are unlikely to disappear, even in an age in which the average person's eyes seem to be perpetually locked on mobile devices. "The quality of the writing and the quality of the narrative matter," says Menon. Classics such as Richard Dawkins' The Selfish Gene (Oxford Univ. Press, 1976) and Primo Levi's 1975 The Periodic Table continue to sell well. They have, says Menon, "a literary quality, a structure and a beauty. There are just a few scientists who can write like that, and that is something to be treasured and valued. I would hope that that continues to have a home." -

Josie Glausiusz is a writer based in Israel. e-mail:josiegz@gmail.com 